\title{
Managing Education in the Global Pandemic: Best Strategy to Carry Out Natural Science Learning
}

\section{Erni Munastwi ${ }^{*}$}

\author{
${ }^{1}$ Sunan Kalijaga State Islamic University Yogyakarta, Indonesia
}

\section{A R T I C L E I N F O}

\section{Article history:}

Received January 20, 2021

Revised February 01, 2021

Accepted April 08, 2021

Available online May 25, 2021

Kata Kunci:

Blended, IPA, prestasi belajar

Keywords:

Blended, Natural Science,

Learning Achievement

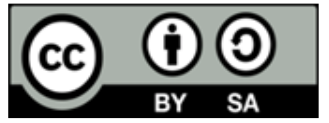

This is an open access article under the CC BY-SA license.

Copyright $(2021$ by Author. Published by Universitas Pendidikan Ganesha.

\begin{abstract}
A B S T R A K
Pandemi covid-19 sangat berdampak pada sektor pendidikan. perubahan proses pembelajaran tatap muka menjadi daring menuntut para pendidik untuk berinovasi menciptakan strategi terbaik dalam pembelajaran tekhusus mata pelajaran ilmu pengetahuan alam di sekolah dasar. Eksplorasi alternatif model belajar mengajar penting dilakukan praktik pendidikan yang optimal kepada para siswa. Penelitian ini bertujuan untuk mengevaluasi prestasi pembelajaran siswa pada pembelajaran IPA, menganalisis dampak metode belajar mengajar dan sumber materi terhadap prestasi siswa, serta menentukan strategi terbaik dalam pengelolaan praktik pendidikan mata pelajaran ilmu pengetahuan alam selama pandemi Covid-19. Eksperimen survei digunakan sebagai desain penelitian, menempati desain faktorial 2x2. Faktor-faktor itu termasuk metode belajar mengajar yang mencakup pembelajaran online dan campuran serta sumber materi belajar mengajar yang mencakup buku pelajaran dan internet. Pengumpulan data dilakukan melalui survei online menggunakan google form. Analisis data dilakukan melalui uji t dan Anova faktorial. Sebagian, hanya metode belajar mengajar yang berdampak signifikan terhadap prestasi belajar siswa, yang ditunjukkan dengan hasil tes-t sebesar -2,610 ( $p=0,010)$. Metode belajar mengajar dan sumber belajar mengajar secara serentak mempengaruhi prestasi siswa terhadap pelajaran ilmu pengetahuan alam. F-test memperoleh nilai $80.335 \quad(p=0.001)$. Perpaduan antara blended learning dan materi belajar mengajar yang bersumber dari internet menghasilkan pencapaian skor yang jauh lebih tinggi.
\end{abstract}

\begin{abstract}
A B S T R A C T
The Covid-19 pandemic has had a major impact on the education sector. changing the face-to-face learning process to online requires educators to innovate to create the best strategies in learning specifically natural science subjects in elementary schools. Exploration of alternative teaching and learning models is important for optimal educational practices for students. This study aims to evaluate student learning achievement in natural science learning, analyze the impact of teaching and learning methods and material resources on student achievement, and determine the best strategy in managing natural science education practice during the Covid-19 pandemic. The survey experiment was used as the research design, occupying a $2 \times 2$ factorial design. These factors include teaching and learning methods that include online and mixed learning as well as teaching and learning material resources that include textbooks and the internet. Data collection was carried out through an online survey using google form. Data analysis was performed through $t$ test and factorial Anova. Partly, only teaching and learning methods have a significant impact on student achievement, as indicated by the t-test result of $-2.610(\mathrm{p}=0.010)$. Teaching and learning methods and teaching and learning resources simultaneously affect student achievement of natural science lessons. The F-test obtained a value of $80,335(p=0.001)$. The combination of blended learning and teaching and learning materials sourced from the internet resulted in the achievement of a much higher score.
\end{abstract}

\section{INTRODUCTION}

Even though the education system is under disruption caused by Covid-19 pandemic, education practice needs to keep its performance in delivering education to the students (Almaiah et al., 2020). Many countries are currently trying to find the best alternative model of education practice (Bozkurt et al., 2020; Munastiwi, 2014). However, since every country has its own characteristic, the best option must be different one and the other. The changes in the paradigm of educational during Covid-19 has shown alternatives in education practice. However, there is no definite model that can be applied in every learning condition, subject, and level. Therefore, continuous development of education model needs to be carried out to improve the performance (Moskal et al., 2013).

The application of online learning has been a standard education system during Covid-19 pandemic (Bozkurt et al., 2020). However, what's further needed is the management of education so that the implementation could be more effective and efficient (Ibrahim et al., 2020). Rather than taking online 
learning as a temporary measure for Covid-19 pandemic, it would be better to maximize its potential. Moreover, online education has been viewed as the potential system of education in the future (Nguyen, 2015). The disruption in educational practice due to Covid-19 pandemic had brought up various strategies in the teaching/learning activity. Education that previously delivered in class base were forced to transform into a digital base Ibrahim et al., 2020). The change of education system had arisen the concern on the effectiveness of teaching/learning method (Bahasoan et al., 2020; Kaur et al., 2020; Khan et al., 2021). Online teaching/learning was brought up in order to overcome the limitation of physical interaction in education (Müller et al., 2021; Rasmitadila et al., 2020). However, it could not be implemented comprehensively. There were many obstacles in the implementation of online teaching/learning, such as unsupportive infrastructure and facility, incompetency of teachers, students, and parents (Putri et al., 2020), to the extent of community's capability to enroll the activity.

Before the Covid-19 pandemic, online learning has never been a part of education system in Indonesia (Putri et al., 2020). Therefore, many school managers still try to find appropriate strategy to optimize the educational practice. Due to the sudden change of education practice, stakeholders such as educational bodies, school managers, teachers, students, and parents were unprepared with standard emergence response. Therefore, school managers and teachers tried to make adjustment of education model in order to deliver education effectively and efficiently (Alea et al., 2020). Because of the limitation in the online teaching/learning practice, many institutions also implemented the blended learning to overcome the problem. Through the implementation of blended learning, the information that cannot be delivered through online teaching/learning activity could be delivered in offline class (Nuraini et al., 2020; Wargadinata et al., 2020). Therefore, the gap of information could be minimized. Another problem that arose was the teaching materials. Covid-19 pandemic had caused disruption in curriculum (Daniel, 2020). Shortage of time and space for education had caused the failure in the delivery of education curriculum comprehensively (Tyagi, 2020). Therefore, modification of curriculum was commonly occurred (Rasmitadila et al., 2020; Roesminingsih et al., 2020). Since the teaching/learning materials should be adjusted to meet the capacity. As the impact, teachers needed to find alternative teaching materials (Martarelli et al., 2021).

Alternative teaching material is important to adjust the teaching/learning program to the current situation. However, education in primary school is generally provided with textbook (Damayanti, 2014; Ibáñez et al., 2019; Kazemian et al., 2014). Textbook had been the main source of teaching materials in education. Fortunately, due to the advancement of information and communication technology, many sources of learning materials become available in the internet (Fasihuddin et al., 2013; Goldman et al., 2012). These are potential source of information that could be used as source of teaching/learning materials. Therefore, many teachers also used the internet as the source of teaching materials (Amenyedzi et al., 2020; Olowa, 2012). Natural science is a study subject that has complexity and difficulty. Natural science for elementary school is an integrated subject that consists of physics, chemistry and biology sciences (Faisal \& Martin, 2019). Therefore, students need both calculation and memorization skills. However, since learning natural science involves experiments and observations (Suendarti, 2017), it would be difficult to perform a full online teaching/learning. Thus, blended learning could be considered as the alternative.

Based on the exposure on trying the best strategy in carrying out primary school science learning, comparing each use of science learning strategy is considered able to help teachers in using science learning strategies in the era of the covid-19 pandemic. Previous research has investigated the implementation of science learning strategies during the pandemic. However, the research still focuses on literature reviews, such as the implementation of science learning using Learning Cycle strategies, Blended Learning, STEAM, E-Learning (Learning Management System) and ethnoscience (Nur Umi Rahmawati \& Rahmawati, 2021). Researchers previously only focused on the final results such as analysis of science process skills during the Covid-19 pandemic there was a good influence in aspects of learning achievements during the covid-19 pandemic (Eliyana, 2020; Sobron et al., 2019). In addition, the researchers also said that in the online implementation of science learning is less effective because it only provides tasks and collects so that the less developed aspects of critical thinking (Handayani, 2021; Rosyada et al., 2021). However, there is still little to test about the influence of science teaching strategy in 4 th grade in elementary schools.

Therefore, this study was conducted to evaluate student learning achievement in natural science learning, analyze the impact of teaching and learning methods and material resources on student achievement, and determine the best strategy in managing natural science education practice during the Covid-19 pandemic. 


\section{METHOD}

The method used in this study was a factorial experiment method (Hajiyakhchali, 2013; Lu et al., 2017; Supriadi et al., 2019). Factorial experiment design is used as a treatment design involving two factors, namely learning methods and material resources. The learning method consists of online and blended learning, while the source material consists of textbooks and the internet. In terms of the internet as a source of learning materials, students access it independently. This study focused on the learning achievement of 115 students of 4th grade, three classes each consisting of 29 students, while one class consisted of only 28 students. The 4 th grade was chosen as the object of research because it was a time when science was separated as independent subjects. Because the experiment used was a factorial design of $2 \times 2$, four classes were involved in this study. The four classes integrate different teaching models that combine learning/teaching methods and material resources. The combination is: online learning with textbooks; online learning with the internet; blended learning with textbooks; and integrated learning with the internet.

Due to the actual condition of the Covid-19 pandemic that limits communal activities, the data collection is done through online surveys. Information on management applied in educational practices is provided by the homeroom teacher. Data is collected using google forms. Teachers provide the information needed for research, such as teaching methods and materials used in teaching and learning activities. Analysis data was carried out through t-test and factorial Anova. T-test was used to analyze the partial impact of teaching/learning method and material source, while factorial Anova was used to analyze the simultaneous impact of both factors. Data analysis was carried out using SPSS with error interval of $5 \%$.

\section{RESULT AND DISCUSSION}

The result showed that students generally got great achievement on natural science subject. Students' score was ranging between 83 to 97 with average of $91.26 \pm 2.85$. The score indicates that there was a significant variation of students' learning achievements. Noticeable difference of score achievement due to the difference of teaching/learning method and material source were obtained. However, significant different was only shown by the effect of teaching/learning method, while the impact of different material source did not signify the impact to the students' learning achievement. The result of the statistical analysis of partial effect of teaching/learning method and material source is presented in Table 1 and

Table 2.

Table 1. Impact of teaching/learning method on 4th grade students' learning achievement in natural science subject

\begin{tabular}{|c|c|c|}
\hline \multirow{2}{*}{$\begin{array}{c}\text { Teaching/Learning } \\
\text { Method }\end{array}$} & \multicolumn{2}{|c|}{ Score } \\
\hline & Range & Average \pm StDev \\
\hline Online & $83-95$ & $90.58 \pm 2.66 a$ \\
\hline Blended & $83-97$ & $91.93 \pm 2.89 b$ \\
\hline
\end{tabular}

Table 1 shows that students' score achievement due to the implementation of blended learning was more variative than the online learning. The average score achievement was also significantly higher. Statistical analysis with $t$-test showed $t$-value of -2.610 and probability of $0.010(p<0.05)$ which indicated that there was a significant impact of teaching/learning method on the score achievement of $4^{\text {th }}$ grade students in natural science subject.

Table 2. Impact of material sources on 4th grade students' learning achievement in natural science subject

\begin{tabular}{lcc}
\hline \multirow{2}{*}{ Material Source } & \multicolumn{2}{c}{ Score } \\
\cline { 2 - 3 } \multicolumn{1}{c}{ Range } & Average \pm StDev \\
\hline Textbook & $83-94$ & $90.95 \pm 2.43 \mathrm{a}$ \\
Internet & $83-97$ & $91.58 \pm 3.21 \mathrm{a}$ \\
\hline
\end{tabular}

Statistical analysis on the impact of material source on the students' learning achievement indicated an insignificant difference. The analysis result showed t-value of -1.190 and probability of 0.237 $(p>0.05)$, which means that the difference between two groups was not significant even though it was 
noticeable. According to the result, the score achievement was higher in the internet group compared to the textbook group. Further analysis was carried out to evaluate the combined effect of teaching/learning method and material source. The combination distinguished further students' learning achievement and extended the result to a deeper understanding. Table 3 shows the detailed difference of students' learning achievement due to the combination of teaching/learning method and material source.

Table 3. Combined effect of teaching/learning methods and material source on learning achievement of 4 th grade elementary school students in natural science subject

\begin{tabular}{lcc}
\hline \multirow{2}{*}{ Material Source } & \multicolumn{2}{c}{ Learning Method } \\
\cline { 2 - 3 } & Online & Blended \\
\hline Textbook & $86-94$ & $83-95$ \\
& $91.10 \pm 2.04 \mathrm{a}$ & $90.79 \pm 2.80 \mathrm{a}$ \\
Internet & $83-94$ & $89-97$ \\
& $90.04 \pm 3.12 \mathrm{a}$ & $93.07 \pm 2.55 \mathrm{~b}$ \\
\hline
\end{tabular}

Table 3 shows how the combination of teaching/learning method and material source differed the achievement of $4^{\text {th }}$ grade students in natural science subject. According to the result, there was a preference of combination between two variables. The implementation of online learning was better when combined with the utilization of textbook as the source of learning material. Blended learning in the other side was better when combined with learning material obtained from the internet. However, the implementation of blended learning that was combined with internet sourced material was significantly resulted in better learning achievement in the subject of natural science. The statistical analysis with factorial Anova showed the F value of 80.335 and probability of $0.001(\mathrm{p}<0.05)$. However, the combination of blended learning and internet sourced material was the only treatment that was different significantly from the other treatments, while the other treatments were not different significantly one to the other even though the differences were noticeable. Referring to the result, the implementation of blended learning combined with internet sourced learning material is suggested to optimize the students' learning achievement in natural science subject for 4 th grade elementary school students.

\section{Discussion}

Engagement of digital technology will be a normal model of education practice after the Covid-19 pandemic has passed (Dwivedi et al., 2020). This is because far before the pandemic, digital pedagogy had been considered to change the shape of education (Lancashire, 2010). Therefore, the outbreak of Covid-19 can be considered as the accelerator of the transformation. As the implication, there will be new standard of pedagogical skill competences, especially for teachers, students, and parents. In the other side, educational institution needs to develop strategic management to optimize the education activities. Implementation of online learning in the educational practice needs further concern on how lessons should be delivered. However, each lesson has different requirement (Gill \& Kusum, 2017). Therefore, it needs different approach. Referring to the result, the implementation of blended learning along with the utilization of internet sourced material signified the improvement of students' achievement in natural science subject.

The result of this research suggested that the combination of blended learning and internet sourced learning material maximized the achievement of $4^{\text {th }}$ grade students in natural science. This could be due to the character of natural science lesson that require deeper understanding through practices or experimentation (Devitasari et al., 2021; Suendarti, 2017). Therefore, students would learn better with assistance than without assistance (Tembang et al., 2018). Blended learning opens the opportunity for students and teachers to interact, communicate, and discuss the lesson (Kaur, 2013). Online learning activity acts as a media to deliver theoretical knowledge, while offline learning activity acts as an opportunity to carry out demonstration, experiments, or practices (Ibrahim et al., 2014; Tafa, 2012). In the meantime, by using internet as source of learning materials, students could explore their curiosity and obtain more information that could be brought up to discuss with the teachers (Bonk \& Lee, 2017). Internet enables student to personalize their preference of materials and method of learning (Intayoad et al., 2017). Along with teachers' assistance during offline learning activity, it could improve their understanding (Ardiyani et al., 2020). Thus, students would obtain better learning achievement.

According to the result of the research, the other combinations provided good support to students' learning process, although the achievements were lower compared to the combination of blended learning and internet sourced materials. However, there was a trend where the combination of online teaching/learning along with the utilization of textbook also provided better achievement, although 
it was still incomparable to the combination of blended learning and internet sourced materials. This showed the compatibility of teaching/learning method and the source of material used. Performing a full online requires an exact or predefined material so that teacher and students have the same topic to discuss. This enables teacher and students to have similar understanding. Therefore, teaching/learning activity can be synchronized even without physical interaction. However, in the natural science learning, it is only effective in delivering the theory only (Bahasoan et al., 2020). Hence, students understanding is shortened.

Full online teaching/learning activity is not effective to be carried out (Ilmadi et al., 2020). Therefore, education practice should not be relied on the full online teaching/learning method. The implementation of online learning by the subject of the study referred to synchronous online learning because it was carried out as a replacement of class learning. Therefore, students did not have the independence to learn according to their own interest. The combination of blended learning and internet sourced materials can be developed into problem-based learning (Liu, 2016). Students who obtain their learning materials from the internet may obtain different kind of information (Fleck, 2012). The raw information needs to be refined through offline class. Thus, teaching/learning activity would have richer content compared to using textbook (Lee et al., 2013). The implementation of one directional teaching in natural science is considered as weakness (Suendarti, 2017). Natural science education requires the integration of laboratory practicum or experiment (Tafa, 2012). Laboratory practice is an important process in natural science learning to develop practical knowledge of the students. Neglecting the practical skill development would result in long-term disadvantage to the students (Gamage et al., 2020). Therefore, relying on full online learning is not appropriate to be applied in natural science subject.

Implementation of discovery learning in natural science is better than conventional learning (Suendarti, 2017). This is comparable to the result of this research which proved that blended learning combined with internet sourced materials was better than online learning or the utilization of textbook. The approach used in discovery learning is problem solving due to the experience and knowledge students obtained (Supriadi et al., 2019). Similar pattern was could be found in the combination of blended learning and internet sourced material in the research. Students independently access the internet to collect learning materials which topic had been determined. Thus, there was a probability that students also obtained additional information that develop their courage. The results of this study contributed as an online learning strategy solution of natural science subjects. through blanded learning strategies and utilizing internet access was able to optimize the learning process of science in elementary schools. Thus this research is able to add empirical evidence about effective strategies in carrying out online learning of natural science subjects, as previously researched by (Handayani, 2021; Nur Umi Rahmawati \& Rahmawati, 2021).

\section{CONCLUSION}

The application of blended learning combined with internet sourced learning materials showed significantly better result that can be suggested as the best option to carry out natural science teaching. But, if the students are unable to contain themselves, the implementation of online learning combined with textbook utilization would be a suitable alternative to optimize students' learning performance. This research still has many shortcomings, so that further research is needed. However, this research can contribute to opening up preliminary information for further research.

\section{REFERENCES}

Alea, L. A., Fabrea, M. F., Roldan, R. D. A., \& Farooqi, A. Z. (2020). Teachers' Covid-19 Awareness, Distance Learning Education Experiences and Perceptions towards Institutional Readiness and Challenges. International Journal of Learning, Teaching and Educational Research, 19(6), 127-144. https: //doi.org/10.26803/ijlter.19.6.8.

Almaiah, M. A., Al-Khasawneh, A., \& Althunibat, A. (2020). Exploring the critical challenges and factors influencing the E-learning system usage during COVID-19 pandemic. Education and Information Technologies, 25(6), 5261-5280. https://doi.org/10.1007/s10639-020-10219-y.

Amenyedzi, F. W. K., Lartey, M. N., \& Dzomeku, B. M. (2020). The Use of Computers and Internet as Supplementary Source of Educational Material: A Case Study of the Senior High Schools in the Tema Metropolis in Ghana. Contemporary Educational Technology, 2(2), 151-162. https://doi.org/10.30935/cedtech/6049.

Ardiyani, D. K., Wijayati, P. H., \& Hidayat, E. (2020). Blended Learning in Teacher Profession Education (PPG) of Germany Education as The 21st Century Teacher Training Model. Journal of Development 
Research, 4(2), 125-133. https://doi.org/10.28926/jdr.v4i2.116.

Bahasoan, A. N., Ayuandiani, W., Mukhram, M., \& Rahmat, A. (2020). Effectiveness of Online Learning In Pandemic Covid-19. International Journal of Science, Technology \& Management, 1(2), 100-106. https://doi.org/10.46729/ijstm.v1i2.30.

Bonk, C. J., \& Lee, M. M. (2017). Motivations, Achievements, and Challenges of Self-Directed Informal Learners in Open Educational Environments and MOOCs. Journal of Learning for Development, 4(1), 36-57. https://j14d.org/index.php/ejl4d/article/download/195/188?inline=1.

Bozkurt, A., Jung, I., Xiao, J., Vladimirschi, V., Schuwer, R., Egorov, G., Lambert, S., Al-Freih, M., Pete, J., Olcott Jr., D., Rodes, V., Aranciaga, I., Bali, M., Alvarez Jr., A., Roberts, J., Pazurek, A., Raffaghelli, J., Panagiotou, N., de Coëtlogon, P., ... Paskevicius, M. (2020). A global outlook to the interruption of education due to COVID-19 Pandemic: Navigating in a time of uncertainty and crisis. Asian Journal of Distance Education, 15(1), 1-126. https://doi.org/10.5281/zenodo.3878572.

Damayanti, I. L. (2014). Gender construction in visual images in textbooks for primary school students. Indonesian Journal of Applied Linguistics, 3(2), 100-116. https://pdfs.semanticscholar.org/9c32/de48110ef8a82297e4ff5021ebc51a4a5b74.pdf.

Daniel, S. J. (2020). Education and the COVID-19 pandemic. Prospects, 49(1-2), 91-96. https://doi.org/10.1007/s11125-020-09464-3.

Devitasari, P. I., Wilujeng, I., Azhary, S. A., \& Sadewo, M. A. I. (2021). Natural Science Module Web that is Integrated With Local Plants Toward Cooperation Skills and Environmental Care Attitude of Students. Journal of Physics: Conference Series, 1(1), 52-57. https://iopscience.iop.org/article/10.1088/1742-6596/1882/1/012094/meta.

Dwivedi, Y. K., Hughes, D. L., Coombs, C., Constantiou, I., Duan, Y., Edwards, J. S., Gupta, B., Lal, B., Misra, S., Prashant, P., Raman, R., Rana, N. P., Sharma, S. K., \& Upadhyay, N. (2020). Impact of COVID-19 pandemic on information management research and practice: Transforming education, work and life. International Journal of Information Management, 55, 102211. https://doi.org/10.1016/j.ijinfomgt.2020.102211.

Eliyana, E. (2020). Analisis Keterampilan Proses Sains Siswa Belajar IPA Materi Tumbuhan Hijau Pada Siswa Kelas V SDN 3 Panjerejo di Masa Pandemi Covid-19. EDUPROXIMA: Jurnal Ilmiah Pendidikan IPA, 2(2), 87. https://doi.org/10.29100/eduproxima.v2i2.1628.

Faisal, \& Martin, S. N. (2019). Science education in Indonesia: past, present, and future. Asia-Pacific Science Education, 5(1), 4. https://doi.org/10.1186/s41029-019-0032-0.

Fasihuddin, H. A., Skinner, G. D., \& Athauda, R. I. (2013). Boosting the opportunities of open learning (MOOCs) through learning theories. GSTF Journal on Computing (JOC), 3(3), 112-117. https://doi.org/10.5176/2251-3043_3.3.280.

Fleck, J. (2012). Blended learning and learning communities: opportunities and challenges. Journal of Management Development, 31(4), 398-411. https://doi.org/10.1108/02621711211219059.

Gamage, K. A. A., Wijesuriya, D. I., Ekanayake, S. Y., Rennie, A. E. W., Lambert, C. G., \& Gunawardhana, N. (2020). Online Delivery of Teaching and Laboratory Practices: Continuity of University Programmes during COVID-19 Pandemic. Education Sciences, 10(10), 291. https://doi.org/10.3390/educsci10100291.

Gill, A. K., \& Kusum. (2017). Teaching Approaches, Methods and Strategy. Scholarly Research Journal for Interdisciplinary Studies, 4(36), 6692-6697. https://doi.org/10.21922/srjis.v4i36.10014.

Goldman, S. R., Braasch, J. L. G., Wiley, J., Graesser, A. C., \& Brodowinska, K. (2012). Comprehending and learning from internet sources: Processing patterns of better and poorer learners. Reading Research Quarterly, 47(4), 356-381. https://doi.org/10.1002/RRQ.027.

Hajiyakhchali, A. (2013). The Effects of Creative Problem Solving Process Training on Academic Wellbeing of Shahid Chamran University Students. Procedia-Social and Behavioral Sciences, 84, 549552. https://doi.org/10.1016/j.sbspro.2013.06.602.

Handayani, N. A. (2021). Analisis Pembelajaran IPA Secara Daring pada Masa Pandemi Covid-19. Jurnal Pendidikan Sains Indonesia, 9(2), 217-233. https://doi.org/10.24815/jpsi.v9i2.19033.

Ibáñez, R., Moncada, F., \& Cárcamo, B. (2019). Coherence Relations in Primary School Textbooks: Variation $\begin{array}{lllll}\text { across School } \quad \text { Subjects. Discourse Processes, } & \text { 56(8), }\end{array}$ https://doi.org/10.1080/0163853X.2019.1565278.

Ibrahim, F., Susanto, H., Haghi, P. K., \& Setiana, D. (2020). Shifting Paradigm of Education Landscape in Time of the COVID-19 Pandemic: Revealing of a Digital Education Management Information System. Applied System Innovation, 3(4), 49. https://doi.org/10.3390/asi3040049.

Ibrahim, N. H., Surif, J., Hui, K. P., \& Yaakub, S. (2014). "Typical” Teaching Method Applied in Chemistry Experiment. Procedia - Social and Behavioral Sciences, 116(2005), 4946-4954. https://doi.org/10.1016/j.sbspro.2014.01.1054. 
Ilmadi, Zarista, R. H., Aden, \& Sastro, G. (2020). The Effectiveness of Online Learning for Mathematics Students During the Covid-19 Pandemic (Case Study-Mathematics Study Program, Pamulang University). Jurnal Cendekia: Jurnal Pendidikan Matematika, 4(2), 1273-1282. https://doi.org/10.31004/cendekia.v4i2.372.

Intayoad, W., Becker, T., \& Temdee, P. (2017). Social Context-Aware Recommendation for Personalized Online Learning. Wireless Personal Communications, 97(1), 163-179. https://doi.org/10.1007/s11277-017-4499-2.

Kaur, M. (2013). Blended Learning - Its Challenges and Future. Procedia - Social and Behavioral Sciences, 93, 612-617. https://doi.org/10.1016/j.sbspro.2013.09.248.

Kaur, N., Dwivedi, D., Arora, J., \& Gandhi, A. (2020). Study of the effectiveness of e-learning to conventional teaching in medical undergraduates amid COVID-19 pandemic. National Journal of Physiology, $\begin{array}{llll}\text { Pharmacy and } & \text { Pharmacology, }\end{array}$ https://doi.org/10.5455/njppp.2020.10.04096202028042020.

Kazemian, R., Ghasemi, H., Movahhed, T., \& Kazemian, A. (2014). Health education in primary school textbooks in iran in school year 2010-2011. Journal of Dentistry, 11(5), 536-544. https://www.ncbi.nlm.nih.gov/pmc/articles/PMC4290773/.

Khan, M. A., Vivek, Nabi, M. K., Khojah, M., \& Tahir, M. (2021). Students' perception towards e-learning during covid-19 pandemic in India: An empirical study. Sustainability (Switzerland), 13(1), 1-14. https://doi.org/10.3390/su13010057.

Lancashire, I. (2010). Digital Pedagogy : Taming the Palantíri. In T. Kayalis \& A. Natsina (Eds.), Teaching Literature at a Distance: Open, Online and Blended Learning (pp. 79-86). Continuum.

Lee, C. S., McNeill, N. J., Douglas, E. P., Koro-Ljungberg, M. E., \& Therriault, D. J. (2013). Indispensable Resource? A Phenomenological Study of Textbook Use in Engineering Problem Solving. Journal of Engineering Education, 102(2), 269-288. https://doi.org/10.1002/jee.20011.

Liu, H. (2016). An Analysis on Blended Learning Pattern Based on Blackboard Network Platform: A Case Study on the Course of Recruitment and Employment Management. International Journal of Emerging Technologies in Learning (IJET), 11(9), 4-8. https://doi.org/10.3991/ijet.v11i09.6124.

Lu, O. H. T., Huang, J. C. H., Huang, A. Y. Q., \& Yang, S. J. H. (2017). Applying learning analytics for improving students engagement and learning outcomes in an MOOCs enabled collaborative programming course. Interactive Learning Environments, 25(2), 220-234. https://doi.org/10.1080/10494820.2016.1278391.

Martarelli, C. S., Pacozzi, S. G., Bieleke, M., \& Wolff, W. (2021). High trait self-control and low boredom proneness help COVID-19 homeschoolers. Frontiers in Psychology, 12, 594256. https://doi.org/10.3389/fpsyg.2021.594256.

Moskal, P., Dziuban, C., \& Hartman, J. (2013). Blended learning: A dangerous idea? The Internet and Higher Education, 18, 15-23. https://doi.org/10.1016/j.iheduc.2012.12.001.

Müller, A. M., Goh, C., Lim, L. Z., \& Gao, X. (2021). COVID-19 Emergency eLearning and Beyond: Experiences and Perspectives of University Educators. Education Sciences, 11(1), 19. https://doi.org/10.3390/educsci11010019.

Munastiwi, E. (2014). The implementation of e-learning in learning process. In S. Siraj, W. A. Bush, \& J. H. Jaidin (Eds.), 2nd International Seminar of Teaching Excellence \& Innovation (pp. 309-318). University of Malaya.

Nguyen, T. (2015). The Effectiveness of Online Learning: Beyond No Significant Difference and Future Horizons. MERLOT Journal of Online Learning and Teaching, 11(2), 309-319. http://jolt.merlot.org/Vol11no2/Nguyen_0615.pdf.

Nur Umi Rahmawati, D., \& Rahmawati, R. (2021). Science learning based on 'merdeka belajar' in elementary school during pandemic. International Conference Fakultas Tarbiyah Dan Keguruan Universitas Islam Negeri Imam Bonjol Padang, 131-137. https://doi.org/10.32698/icftk413.

Nuraini, N. L. S., Qihua, S., Venatius, A. S., Slamet, T. I., \& Cholifah, P. S. (2020). Distance Learning Strategy in Covid-19 Pandemic for Primary Schools. Proceeding International Webinar Series - Educational Revolution in Post Covid Era "Teaching and Evaluation for Children in Covid Era," 107-116.

Olowa, 0. W. (2012). An Assessment of Internet Uses, Practices, and Barriers for Professional Development by Agricultural Science Teachers in Lagos State. Education Research International, 2012, 503264. https://doi.org/10.1155/2012/503264.

Putri, R. S., Purwanto, A., Pramono, R., Asbari, M., Wijayanti, L. M., \& Hyun, C. C. (2020). Impact of the COVID-19 Pandemic on Online Home Learning: An Explorative Study of Primary Schools in Indonesia. International Journal of Advanced Science and Technology, 29(5), 4809-4818.

Rasmitadila, R., Aliyyah, R. R., Rachmadtullah, R., Samsudin, A., Syaodih, E., Nurtanto, M., \& Tambunan, A. R. S. (2020). The Perceptions of Primary School Teachers of Online Learning during the COVID-19 
Pandemic Period: A Case Study in Indonesia. Journal of Ethnic and Cultural Studies, 7(2), 90. https://doi.org/10.29333/ejecs/388.

Roesminingsih, M. V., Nusantara, W., Nugroho, R., Rachmadyanti, P., \& Gunansyah, G. (2020). Development of Independent Homeschooling Model Primary School Division as the Impact of Covid 19. Proceedings of the International Joint Conference on Arts and Humanities (IJCAH 2020), 491(IJCAH), 1238-1242. https://doi.org/10.2991/assehr.k.201201.207.

Rosyada, M. I., Atmojo, I. R. W., \& Saputri, D. Y. (2021). Dampak implementasi pembelajaran dalam jaringan (daring) mengenai kualitas pembelajaran ipa di sekolah dasar pada masa pandemi covid19. In Didaktika Dwija Indria (Vol. 9, Issue 4). https://doi.org/10.20961/DDI.V9I4.49180.

Sobron, Bayu, Rani, \& Meidawati. (2019). Pengaruh Daring Learning terhadap Hasil Belajar IPA Siswa Sekolah Dasar. Seminar Nasional Sains \& Entrepreneurship, 1(1).

Suendarti, M. (2017). The Effect of Learning Discovery Model on the Learning Outcomes of Natural Science of Junior High School Students Indonesia. International Journal of Environmental and Science Education, $12(10)$, http://www.ijese.net/makale_indir/IJESE_1988_article_5a2e4e6b83fea.pdf.

Supriadi, N., Syazali, M., Lestari, B. D., Dewi, E. S., Utami, L. F., Mardani, L. A., \& Putra, F. G. (2019). The Utilization of Project Based Learning and Guided Discovery Learning: Effective Methods to Improve Students' Mathematics Ability. Al-Ta Lim Journal, 25(3), 261-271. https://doi.org/10.15548/jt.v25i3.487.

Tafa, B. (2012). Laboratory Activities and Students Practical Performance: The Case of Practical Organic Chemistry I Course of Haramaya University. African Journal of Chemical Education, 2(3), 47-76.

Tembang, Y., Purwanty, R., Palobo, M., Tahapary, R., Hermansyah, A. K., \& Dadi, O. (2018). The Implementation Of Think Pair Share Model With Interactive Cd Assistance To Improve The Learning Outcomes Of Natural Science Subject Of Elementary School Students. Proceedings of the 1st International Conference on Social Sciences (ICSS 2018), 226(Icss), 1371-1376. https://doi.org/10.2991/icss-18.2018.289.

Tyagi, H. (2020). Online teaching in Delhi-NCR schools in India during Covid-19 pandemic. Indian Journal of Science and Technology, 13(38), 4036-4054. https://doi.org/10.17485/IJST/v13i38.1613.

Wargadinata, W., Maimunah, I., Dewi, E., \& Rofiq, Z. (2020). Student's Responses on Learning in the Early COVID-19 Pandemic. Tadris: Jurnal Keguruan Dan Ilmu Tarbiyah, 5(1), 141-153. https://doi.org/10.24042/tadris.v5i1.6153. 